\title{
JEKK
}

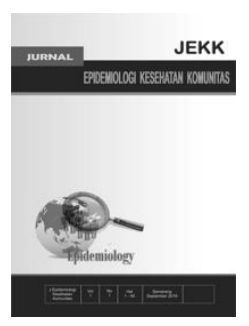

\section{Hubungan Pengetahuan Dan Jumlah Pasangan Seksual dengan Risiko HIV pada Wanita Pekerja Seksual (WPS) di Kota Ternate}

\author{
Nita Anggerina Putri Hi Setiawan*, Dwi Sutiningsih"*, Bagoes Widjanarko** \\ *Magister Epidemiologi, Universitas Diponegoro, Semarang \\ ***Fakultas Kesehatan Masyarakat, Universitas Diponegoro, Semarang
}

\begin{abstract}
Background: The number of HIV/AIDS cases in Ternate is increasing, until now there are 472 cases reported and in 2019 there were 46 new cases. FSW is one of the key population at risk of HIV. The purpose of this study was to identify the correlation between knowledge and number of sexual partner with HIV risk among female sex workers (FSW) in Ternate

Methods: This study was an observational study with a cross-sectional design conducted at Ternate City. The number of respondents was 92 respondents. The instrument used in this study was a questionnaire. Data analysis was univariate, and bivariate with chi-square.

Result: There were correlation between knowledge ( $\mathrm{p}=0,013$; PR 1,363; 95\% CI 1,069-1,704), and the number of sexual partners $(\mathrm{p}=0.030$; PR 1,497; 95\% CI 0,961-2,331) with HIV risk among FSW in Ternate.
\end{abstract}

Conclusion : FSW who had poor knowledge and had $\geq 3$ clients, was correlated with HIV risk.

Keywords: HIV; FSW; Knowledge; Number of Sexual Partners.

*Penulis korespondensi, nitaputrisetiawan@gmail.com 


\section{Pendahuluan}

HIV (Human Immunodeficiency Virus) adalah retrovirus yang menginfeksi sel-sel sistem kekebalan tubuh manusia (terutama sel$\mathrm{T} \mathrm{CD} 4^{+}$dan makrofag) dan menghancurkan atau merusak fungsinya. Sedangkan AIDS (Acquired Immunodeficiency Deficiency Syndrom) adalah kumpulan gejala dan infeksi yang terkait dengan defisiensi sistem imun yang didapat. Timbul penyakit tertentu yang disebut dengan infeksi oportunistik yaitu TBC, infeksi paru-paru yang menyebabkan radang paru-paru dan kesulitan bernafas, kanker, khususnya sariawan, kanker kulit atau sarcoma kaposi, infeksi usus yang menyebabkan diare parah berminggu-minggu, dan infeksi otak yang menyebabkan kekacauan mental dan sakit kepala. Infeksi dengan HIV telah ditetapkan sebagai penyebab utama AIDS. ${ }^{1}$

HIV/AIDS terus menjadi masalah utama kesehatan global. Secara global, 38 juta orang hidup dengan HIV sampai dengan akhir tahun 2019 (36,2 juta orang dewasa di mana sebanyak 19,2 juta wanita dan 17 juta pria, kemudian 1,8 juta anak-anak usia $<15$ tahun). ${ }^{2}$ Sedangkan kasus HIV di Indonesia, pada tahun 2018 yaitu sebanyak 640.000 orang hidup dengan HIV. Persentase orang yang hidup dengan HIV di antara orang dewasa (15-49 tahun) adalah $0,4 \%$. Sebanyak 46.000 orang baru terinfeksi HIV, dan 38.000 orang meninggal karena penyakit terkait AIDS. $^{3} \mathrm{Di}$ Kota Ternate sendiri, berdasarkan data Dinas Kesehatan, tercatat bahwa jumlah kasus HIV/AIDS yaitu sebanyak 472 kasus, dan tahun 2019 terdapat 46 kasus baru. Pada kelompok berisiko, khususnya WPS terdapat jumlah kasus baru yaitu 27 kasus. Angkaangka tersebut belum termasuk dari mereka yang tidak melaporkan status HIV positif. ${ }^{4}$

Peluang HIV ditularkan melalui hubungan seksual cukup besar, maka hubungan bergantiganti pasangan merupakan faktor khusus yang perlu diwaspadai. ${ }^{5}$ Kontak seksual tanpa perlindungan dengan banyak klien atau pasangan meningkatkan kerentanan terhadap infeksi HIV. Pekerja seks adalah salah satu populasi berisiko tinggi dengan sejumlah besar klien atau banyak pasangan seksual. $^{6} \mathrm{Di}$ Indonesia, mayoritas WPS menjual seks kepada laki-laki. Jumlah klien WPS dalam seminggu terakhir bervariasi di setiap provinsi. Berdasarkan IBBS 2007, jumlah klien untuk WPS langsung berkisar antara 2-7 di Papua dan 8-22 di Bali, sementara untuk WPS tak langsung, jumlah klien adalah yang paling sedikit misalnya di Papua (0-2), dan tertinggi di Jakarta dengan 3-9 klien dalam seminggu terakhir. ${ }^{7}$

Pengetahuan adalah salah satu penentu utama perilaku orang. Pengetahuan yang komprehensif tentang HIV dapat menyebabkan perubahan perilaku seksual dan juga mengurangi stigma yang terkait dengan HIV yang disebabkan oleh kesalahpahaman tentang bagaimana HIV menyebar. ${ }^{8,9}$ Pengetahuan juga dapat memotivasi WPS untuk melakukan seks yang lebih aman (misalnya penggunaan kondom) untuk melindungi diri dari infeksi HIV. ${ }^{10,11}$

Penularan HIV dapat disebabkan oleh beberapa faktor, salah satu faktor utama yaitu faktor individu antara lain pengetahuan dan jumlah pasangan seksual WPS. Oleh karena itu, sehingga tujuan penelitian ini adalah untuk mengetahui hubungan dari faktor individu tersebut (pengetahuan dan jumlah pasangan seksual) dengan risiko HIV pada WPS di Kota Ternate.

\section{Metode}

Penelitian ini menggunakan desain cross sectional, bertujuan untuk mengetahui hubungan pengetahuan dan jumlah pasangan seksual dengan risiko HIV pada WPS. Populasi dalam penelitian ini adalah seluruh WPS yang ada di Kota Ternate, di mana jumlah sampel sebanyak 92 orang. Data yang digunakan merupakan data sekunder dari Dinas Kesehatan Kota Ternate serta data primer berupa wawancara dengan membagikan kuesioner kepada responden. Penelitian ini telah mendapatkan izin etik dari Komisi Etik Penelitian Kesehatan, Fakultas Kedokteran, Universitas Diponegoro Semarang.

Analisis data penelitian dilakukan secara univariat, dan bivariat. Analisis univariat untuk melihat distribusi frekuensi setiap variabel. Dan bivariat untuk melihat hubungan variabel independen dengan variabel dependen, menggunakan uji chi square. 


\section{Hasil Penelitian}

Hasil penelitian menunjukkan sebagian besar responden berumur 22-35 tahun (58,7\%), dengan status perkawinan reponden adalah cerai hidup/cerai mati $(66,3 \%)$, dan pendidikan sebagian besar responden dapat dikatakan tergolong cukup rendah, yaitu pendidikan terakhir tamat SMP $(42,4 \%)$ dan tamat SD $(30,4 \%)$.

Berdasarkan tabel 1, bahwa risiko HIV lebih banyak terdapat pada responden yang memiliki pengetahuan buruk (90\%) dibandingkan responden yang pengetahuannya baik $(66,7 \%)$. Hasil analisis menggunakan uji chi-square menunjukan nilai $p=0,013$ ( $p$ $<0,05)$, hal ini berarti ada hubungan yang signifikan antara pengetahuan dengan risiko HIV pada WPS (PR 1,363; 95\%CI 1,069$1,704)$.

Tabel 1. Hasil Analisis Hubungan Pengetahuan dengan Risiko HIV pada WPS di Kota Ternate

\begin{tabular}{|c|c|c|c|c|c|c|c|c|}
\hline \multirow{3}{*}{$\begin{array}{c}\text { Pengeta } \\
\text { huan }\end{array}$} & \multicolumn{4}{|c|}{ Risiko HIV } & & & \multirow{3}{*}{ PR (95\% CI) } & \multirow{3}{*}{$p$-value } \\
\hline & \multicolumn{2}{|c|}{ Berisiko } & \multicolumn{2}{|c|}{$\begin{array}{c}\text { Tidak } \\
\text { Berisiko }\end{array}$} & \multicolumn{2}{|c|}{ Total } & & \\
\hline & $\mathbf{n}$ & $\%$ & $\mathbf{n}$ & $\%$ & $\mathbf{n}$ & $\%$ & & \\
\hline Buruk & 45 & 90 & 5 & 10 & 50 & 100 & & \\
\hline Baik & 28 & 66,7 & 14 & 33,3 & 42 & 100 & $\begin{array}{c}1,363(1,069- \\
1,704)\end{array}$ & 0,013 \\
\hline
\end{tabular}

Berdasarkan tabel 2, bahwa risiko HIV lebih banyak terdapat pada responden yang memiliki jumlah pasangan seksual $\geq 3$ orang $(84,2 \%)$ dibandingkan responden yang jumlah pasangan seksualnya $<3$ orang $(56,3 \%)$. Hasil analisis menggunakan uji chi-square menunjukan nilai $p=0,030 \quad(p<0,05)$, hal ini berarti ada hubungan yang signifikan antara jumlah pasangan seksual dengan risiko HIV pada WPS (PR 1,497; 95\%CI 0,961-2,331).

Tabel 2. Hasil Analisis Hubungan Jumlah Pasangan Seksual dengan Risiko HIV pada WPS di Kota Ternate

\begin{tabular}{|c|c|c|c|c|c|c|c|c|}
\hline \multirow{3}{*}{$\begin{array}{c}\text { Jumlah } \\
\text { Pasangan } \\
\text { Seksual }\end{array}$} & \multicolumn{4}{|c|}{ Risiko HIV } & & & \multirow{3}{*}{ PR $(95 \%$ CI $)$} & \multirow{3}{*}{$p$-value } \\
\hline & \multicolumn{2}{|c|}{ Berisiko } & \multicolumn{2}{|c|}{$\begin{array}{c}\text { Tidak } \\
\text { Berisiko }\end{array}$} & \multicolumn{2}{|c|}{ Total } & & \\
\hline & $\mathbf{n}$ & $\%$ & $\mathbf{n}$ & $\%$ & $\mathbf{n}$ & $\%$ & & \\
\hline$\geq 3$ orang & 64 & 84,2 & 12 & 15,8 & 76 & 100 & & \\
\hline$<3$ orang & 9 & 56,3 & 7 & 43,8 & 16 & 100 & $\begin{array}{c}1,497(0,961- \\
2,331)\end{array}$ & 0,030 \\
\hline
\end{tabular}




\section{Pembahasan}

Penularan heteroseksual dikenal sebagai mode utama dari epidemi HIV/AIDS. WPS dan kliennya rentan terhadap infeksi HIV dan menjadi jembatan penularan HIV dari populasi berisiko tinggi ke populasi umum berisiko rendah. $^{12}$

Pengetahuan yang diukur dalam penelitian ini adalah HIV/AIDS merupakan jenis penyakit apa, penyebab, cara penularan, gejala-gejala, tempat pemeriksaan HIV, cara mendeteksi, dan mencegah HIV. Diperoleh bahwa, sebagian besar WPS memiliki pengetahuan yang buruk. Banyak dari mereka beranggapan bahwa HIV bukanlah jenis penyakit menular, HIV disebabkan oleh bakteri, WPS juga tidak mengetahui gejala-gejala HIV, tempat pemeriksaan HIV dan bagaimana mencegah penyakit tersebut. Rendahnya pengetahuan tentang gejala-gejala HIV dapat membuat WPS yakin bahwa mereka tidak mungkin dapat tertular HIV dan menunda pencarian layanan kesehatan.

Berdasarkan hasil analisis bivariat bahwa ada hubungan antara pengetahuan dengan risiko HIV pada WPS $(p=0,013)$. Penelitian ini sejalan dengan penelitian yang dilakukan di Kota Medan tahun 2019, bahwa terdapat hubungan antara pengetahuan dengan kejadian HIV pada WPS $(p=0,001)$.

Pengetahuan merupakan domain yang sangat penting untuk terbentuknya perilaku seseorang, dengan kata lain pengetahuan mempunyai pengaruh sebagai motivasi awal bagi seseorang dalam berperilaku. ${ }^{13}$ Semakin kecil jumlah praktik seksual tidak aman, semakin besar pengetahuan perempuan tentang HIV/AIDS. ${ }^{14}$ WPS yang mengetahui pentingnya memakai kondom dalam upaya pencegahan HIV dan IMS maka semakin konsisten dalam penggunaan kondom saat berhubungan seksual. ${ }^{14}$

\section{Jumlah Pasangan Seksual}

WPS di Kota Ternate sebagian besar memiliki jumlah pasangan seksual $\geq 3$ orang, dan klien-klien tersebut sebagian besar juga tidak menggunakan kondom. Hasil analisis bivariat mengungkapkan bahwa ada hubungan antara jumlah pasangan seksual dengan risiko
HIV pada WPS $(p=0,030)$. Penelitian ini sejalan dengan penelitian yang dilakukan di Yunnan, Cina tahun 2014, bahwa terdapat hubungan antara jumlah pasangan seksual dengan infeksi HIV pada WPS ( $p=0,001)$.

Penelitian ini tidak sejalan dengan penelitian yang dilakukan di Puskesmas Padang Bulan Kota Medan tahun 2019, bahwa tidak terdapat hubungan antara jumlah pasangan seksual dengan kejadian HIV pada WPS ( $p$ value $=0,397$ ). Dan penelitian yang dilakukan di Tanzania tahun 2017, di mana membuktikan bahwa tidak terdapat hubungan antara jumlah pasangan seksual dengan kejadian HIV pada WPS ( $p$ value $=0,89$ ). Hal ini dikarenakan klien WPS menggunakan kondom secara konsisten, mereka sadar akan pentingnya penggunaan kondom untuk mencegah penyakit menular seksual.

WPS dan kliennya merupakan populasi jembatan yang menyebarkan HIV/AIDS dari kelompok berisiko tinggi ke populasi umum. ${ }^{15}$ Memiliki banyak pasangan merupakan salah satu faktor risiko infeksi HIV. Faktor risiko ini bersama dengan penggunaan kondom yang rendah memberikan kontribusi yang sangat besar terhadap penularan HIV pada WPS. Setiap WPS biasanya harus menjamu lebih dari dua klien per hari dan terkadang lebih dari satu klien dalam satu kesempatan ("seks berkelompok"). Selain seks tanpa kondom, banyak pasangan membuat WPS lebih rentan terhadap infeksi HIV karena kemungkinan trauma epitel vagina yang memudahkan penularan HIV. ${ }^{16}$

\section{Kesimpulan}

Terdapat hubungan antara pengetahuan $(\mathrm{p}=$ 0,013; PR 1,363; 95\%CI 1,069-1,704), dan jumlah pasangan seksual ( $\mathrm{p}=0,030$; PR 1,497; 95\%CI 0,961-2,331) dengan risiko HIV pada WPS di Kota Ternate. Perlunya memberikan edukasi kepada WPS terkait HIV dan IMS, oleh petugas kesehatan atau penjangkau sehingga diharapkan dapat meningkatkan pengetahuan mereka dan mampu mencegah HIV. Kemudian perlu juga melakukan promosi penggunaan kondom pada WPS dan kliennya. 


\section{Ucapan Terima Kasih}

Ucapan terima kasih disampaikan kepada Lurah Muhajirin dan Lurah Bastiong Talangame, Kota Ternate.

\section{Daftar Pustaka}

1. UNAIDS. 2019. HIV and AIDS - Basic Facts [Internet]. Available from: https://www.unaids.org/en/frequentlyasked-questions-about-hiv-and-aids

2. UNAIDS. 2020. AIDS by the Number [Internet].. Available from: https://www.unaids.org/en.

3. UNAIDS. Country Indonesia [Internet]. 2019. Available from: https://www.unaids.org/en/regionscountrie s/countries/indonesia

4. Dinas Kesehatan Kota Ternate. 2018. Profil Dinas Kesehatan Kota Ternate.

5. Center for Disease Control and Prevention. 2020. HIV Risk Behaviors; Available from:

https://www.cdc.gov/hiv/risk/estimates/ris kbehaviors.html

6. WHO,UNFP,UNAIDS. 2012. Prevention and Treatment of HIV and Other Sexually Transmitted Infections for Sex Workers in Low- and Middle-Income Countries Recommendation for a Public Health Approach.

7. Indonesian $\mathrm{MOH}$. 2007. Indonesia NAC FHI. IBBS Among Most-at-Risk Groups (MARG) in Indonesia 2007 - Surveillance Highlights High Risk Men.

8. Swenson RR, Rizzo CJ, Brown LK, Vanable PA, Carey MP VR. 2010. HIV Knowledge and Its Contribution to Sexual Health Behaviors of Low-Income African American Adolescents. J Natl Med Assoc. 102 (12): 1173-83.

9. Ochako R, Ulwodi D, Njagi P KSO. 2011. Trends and Determinants of
Comprehensive HIV and AIDS Knowledge Among Urban Young Women in Kenya. AIDS Res Ther.110 (4): 8:11.

10. Mardiana. 2012. Hubungan Sosiodemografi, Pengetahuan, dan Sikap Pekerja Seks Komersial (PSK) dengan Upaya Pencegahan HIV/AIDS di Kecamatan Bangko Kabupaten Rokan Hilir Propinsi Riau (The Correlation of Sociodemographic, Knowledge, and Attitude of Commercial Sex Workers) w. Univ North Sumatera. 110 (12): 42-6.

11. Bruce E, Bauai L, Sapuri M, Kaldor JM FCKL. 2012. HIV Knowledge, Risk Perception, and Safer Sex Practices Among Female Sex Workers in Port Moresby, Papua New Guinea. Int J Womens Heal.

12. Zhu J, Yuan R, Hu D, Zhu Z, Wang N WB. 2018. HIV Prevalence and Correlated Factors of Female Sex Workers and Male Clients in a Border Region of Yunnan Province, China. Int J STD AIDS. 29 (5): 424-34.

13. Pasaribu RS, Andayani LS. 2019. HIV Pada WPS (Wanita Pekerja Seks) Di Klinik VCT (Voluntary Counseling And Testing ) Wilayah Kerja Puskesmas Padang Bulan. Mutiana Ners. 2 (1): 16877.

14. Patrício ACF de A, Bezerra VP, Nogueira JA, Moreira MASP, Camargo BV, Santos J de S. 2019. Knowledge of sex workers about HIV/AIDS and its influence on sexual practices. Rev Bras Enferm. 72(5): 1311-7.

15. Liu H, Zhao M, Wang Y, Feldman MW, Xiao Q. 2020. The sexual networks of female sex workers and potential HIV transmission risk: an entertainment venuebased study in Shaanxi, China. Int J STD AIDS. 31 (5): 402-9.

16. Septarini NW. 2014. The Social and Environmental Determinants of HIV Infection in Female Sex Workers in 
Indonesia. J Ilmu Kesehatan Masy. 5 (1): $1-8$. 